\title{
Yield and vigor of corn seeds under the influence of flooding periods
}

\author{
Manoela Andrade Monteiro ${ }^{1 *}$, Geison Rodrigo Aisenberg ${ }^{1}$, Felipe Koch ${ }^{1}$, Guilherme Menezes \\ Salau ${ }^{1}$, João Pedro de Oliveira Behenck ${ }^{1}$, Gustavo Henrique Demari ${ }^{1}$, Vinícius Jardel \\ Szareski ${ }^{1}$, Ivan Ricardo Carvalho ${ }^{2}$, Maicon Nardino ${ }^{3}$, Luis Osmar Braga Schuch ${ }^{1}$, Tiago Pedó ${ }^{\text {, }}$ \\ Franscisco Amaral Villela ${ }^{1}$ and Tiago Zanatta Aumonde ${ }^{1}$ \\ ${ }^{1}$ Department of Plant Science, Agronomy School Eliseu Maciel, Federal University of Pelotas - UFPel, Campus Capão \\ do Leão, s/n, 96010-165, Rio Grande do Sul, Brazil. \\ ${ }^{2}$ Departament of Plant Genomics and Breeding Center, Federal University of Pelotas - UFPel, Campus Capão do Leão, \\ s/n, 96010-165, Rio Grande do Sul, Brazil. \\ ${ }^{3}$ Departament of Mathematics and Statistics, Federal University of Pelotas - UFPel, Campus Capão do Leão, s/n, \\ 96010-165, Rio Grande do Sul, Brazil.
}

Received 27 June, 2016; Accepted 3 August, 2016

\begin{abstract}
The aim of this work was to characterize the physiological performance and some of the yield attributes of maize seeds in response to periods of temporary flooding. The study was conducted in an experimental design of randomized blocks, with four treatments composed by four replications, being evaluated the germination, the first count of germination, the germination speed index, the thousand seed weight, the number of seeds per ear, the number of rows per ear, the electrical conductivity in seeds, the length of shoot and primary root and the dry matter of shoot and primary root. Thousand seed weight, number of seeds per ear, number of rows per ear and electrical conductivity in seeds were reduced when plants were exposed to a $72 \mathrm{~h}$ flooding period. The flooding period of $72 \mathrm{~h}$ adversely affects the growth, the physical characteristics and the vigor of maize seeds.
\end{abstract}

Key words: Zea mays L., number of seeds, thousand seed weight, electrical conductivity, initial growth.

\section{INTRODUCTION}

Corn belongs to the family Poaceae. It is cultivated in tropical, subtropical and temperate climates. The area cultivated with this species in Brazil in the first 2014/15 the second harvest was $9,587.6$ ha. The yield in the main regions with corn cultivation in southern Brazil, under favorable soil and weather conditions, is 12-13 $\mathrm{t} \mathrm{ha}^{-1}$ (Conab, 2015). This species responds to the interaction of climatic elements. Solar radiation, precipitation and temperature are factors that exert the greatest influence on the culture because they affect the physiology of plants (Brachtvogel et al., 2009). In general, soil flooding reduces the diffusion of ethylene and increases its endogenous concentration in plant tissues (Yin et al., 2009), leading to a reduction in leaf area and leaf area

${ }^{*}$ Corresponding author. E-mail: manu_agro@hotmail.com.

Author(s) agree that this article remain permanently open access under the terms of the Creative Commons Attribution License 4.0 International License 
ratio (Gazolla Neto et al., 2012). It also increases the concentration of starch in leaves (Irfan et al., 2010) and reduces photosynthetic rates due to retro-inhibition (Araya et al., 2006), and forming short chain aliphatic organic acids in the soil (Schmidt et al., 2010). The metabolic pathway used is anaerobic fermentation, has a lower energy production (Bailey Serres and Voesenek, 2008).

Seed quality relates to environmental conditions under which the plant and the seed develop, comprising characteristics that determine the value for sowing (Marcos Filho, 2005). For its determination, the germination test is used. This test is conducted under suitable environment conditions in order to reproduce conditions closer to those found in the field, and therefore, tests such as electrical conductivity and plant growth, concerning mass and length, are developed (Peske et al., 2012). The change in the metabolism and photosynthetic rates alters plant growth and development. It may reduce seed quality and cause a reduction in yield attributes. There may be different responses according to species and genotypes (Pryor et al., 2006). By studying the effect of soil flooding on soybean plants, Ludwig (2010) observed a reduction in the physiological performance of seeds of plants exposed to flooding. Thomas and Costa (2010) reported that flooding during the vegetative stage has a negative effect on plant growth and consequently on the potential yield of seeds.

For Brachiaria spp. plants, Caetano and Dias-Filho (2008) noted a decrease in relative growth rate in three accessions from six accessions studied. Except for one accession, the authors noted that flooding reduced net photosynthesis, stomatal conductance and transpiration of accessions. Dias-Filho (2005), studying Brachiaria brizantha cv. Marandu, B. decumbens and B. humidicola on flooded soils, observed a high negative correlation between starch accumulation in leaves and photosynthetic capacity of these species. In this context, the aim of this study was to characterize the physiological performance and some attributes of corn seed yield in response to temporary flooding periods.

\section{MATERIALS AND METHODS}

The experiment was conducted at a didactic and experimental field located at the Campus Capão do Leão of the Federal University of Pelotas. Its geographical location is $31^{\circ} 52^{\prime} \mathrm{S}$ and $52^{\circ} 21^{\prime} \mathrm{W}$. The values for physiological performance were determined at the Laboratório Didático de Análise de Sementes do Departamento de Fitotecnia, Programa de Pós-Graduação em Ciência e Tecnologia de Sementes (Didactic Laboratory of Seed Analysis of the Department of Plant Science, Graduate Program in Science and Seed Technology). To obtain the seeds used in determining response to flooding periods, a cultivation of a corn genotype (Zea mayz L.) was performed from propagation material with 95\% germination. This material was collected from the municipality of Ametista do Sul, Rio Grande do Sul state, at geographical

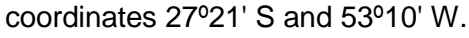

The plants were grown in a Hydromorphic Planosol with a sandy loam texture (Embrapa, 1999). The treatments consisted of periods of flooding in the vegetative stage between V8 and V9, after 75 days of sowing, as follows: zero (soil kept at field capacity); $24 ; 48$ and $72 \mathrm{~h}$ of flooding. The spacing between lines and plants was 45 and 36 centimeters, respectively, resulting in a population density of 55,000 plants ha ${ }^{-1}$ (Borghi and Crusciol, 2007). The soil correction was performed in accordance with a previous analysis and the recommendation by the (Cqfs, 2004). The irrigation was made when there were drought periods. To establish the soil flooding, "marachas" (rows) were opened in the vicinity of each plot, characterizing a beam system. Soil flooding periods were imposed from overflow, with a water depth of $20 \mathrm{~mm}$ above the soil, within beams. After each period, the opening of "marachas" (rows) of beams was performed, and the withdrawal of the water blade and soil drainage was performed.

After the end of the development cycle, at 150 days after sowing, seeds were harvested with moisture of $35 \%$, and the ears were dried in an oven at $30^{\circ} \mathrm{C}$ until they reached a moisture of $14 \%$. Subsequently, seeds were threshed by hand. To evaluate the effects of flooding periods on physiological performance and yield of corn seeds, the following tests were performed:

a) Electric conductivity test: conducted with four replications, with 25 seeds, using a predetermined paste. Seeds were placed in polyethylene containers for soaking in $75 \mathrm{ml}$ of deionized water and then placed in a BOD germinator at $25^{\circ} \mathrm{C}$. After 6,12 and $24 \mathrm{~h}$ of soaking, the readings were performed on a DM-32 conductivity meter. The results were expressed in $\mu S \mathrm{~cm}^{-1} \mathrm{~g}^{-1}$.

b) Mass of thousand seeds: determined from eight subsamples with 100 seeds. The results were expressed in grams (g) according to the Rules for Seed Analysis (Brasil, 2009).

c) Number of rows of seed per ear: determined by direct counting using four subsamples with ten ears per treatment. The results were expressed as average number of rows of seed per ear.

d) Number of seeds per ear: direct counting of the number of seeds per ear. For this, ten subsamples with 10 ears per treatment were used. The results were expressed as average number of seeds per ear.

e) Germination: The test was conducted with four subsamples with 50 seeds per treatment, and the seeds were disposed between three sheets of germination paper, moistened with water at a ratio of 2.5 times the mass of the dry paper. Paper rolls were formed and then transferred to a BOD growth chamber at $25^{\circ} \mathrm{C}$. The evaluation was performed seven days after sowing and the results were expressed as percentage of normal seedlings (Brasil, 2009).

f) First counting of germination: performed jointly to the germination test, four days after sowing, according to Rules for Seed Analysis. The results were expressed as percentage of normal seedlings (Brasil, 2009).

g) Germination speed index: obtained from daily counts of germinated seeds with a minimal root protrusion of 3 to $4 \mathrm{~mm}$. Counts were performed to obtain the constant number of germinated seeds and the germination speed index was established according to the recommendation by (Nakagawa, 1994).

h) Shoot and primary root length of seedlings: four subsamples with 10 seedlings were selected at the end of the germination test. The shoot length was obtained by measuring the distance between the insertion of the basal portion of the primary root, and the primary root length was measured by the distance between its apical and basal parts. The results are expressed in millimeters per seedling ( $\mathrm{mm}$ seedling $\left.{ }^{-1}\right)$.

i) Shoot and primary root dry mass: obtained from four subsamples with 10 seedlings at the end of the germination test. For this, the seedlings were packaged in brown paper envelopes and dried in a forced ventilation oven at $70^{\circ} \mathrm{C}$ until constant weight. The results are expressed in milligrams per seedling $\left(\mathrm{mg} \mathrm{seedling}^{-1}\right)$. 

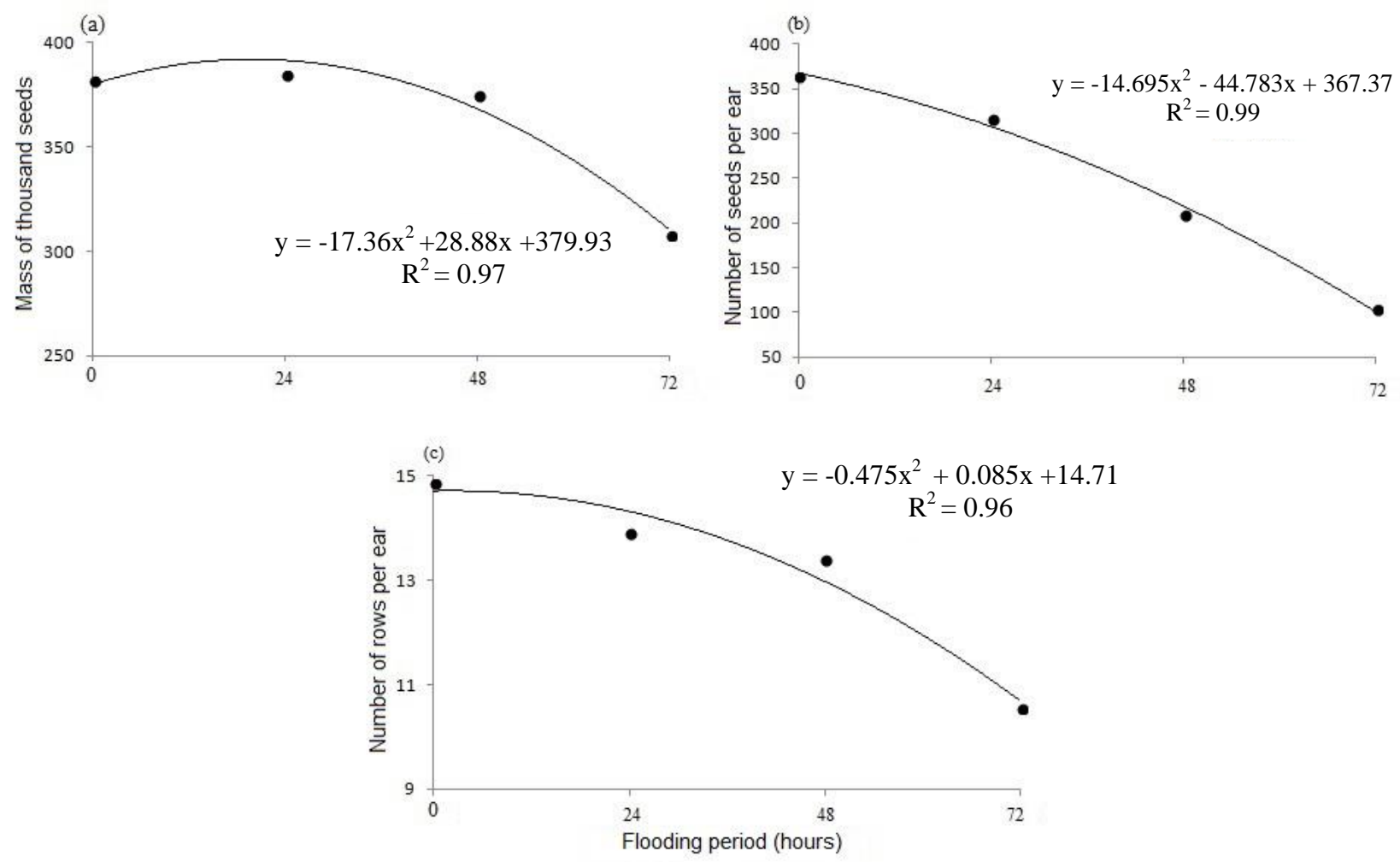

Figure 1. Mass thousand seeds (a), number of seeds per ear (b) and number of rows per ear (c) in corn ( $Z$. mays L.) grown under condition of periods of temporary flooding of $0 ; 24 ; 48$ and $72 \mathrm{~h}$.

The experimental design was randomized blocks with four treatments. Data were submitted to analysis of variance. When significant at $5 \%$ probability, the results were expressed by orthogonal polynomials.

\section{RESULTS AND DISCUSSION}

There was no significant difference at $5 \%$ probability for germination, first counting, germination speed index, root length and root dry matter when evaluating the physiological performance of corn seeds subjected to temporary flooding periods (data not shown). However, the response to imposed stress depends on the inherent characteristics of each species. Gehling et al. (2015) observed that rye seeds produced under the influence of flooding, reduced germination by reducing the number of normal seedlings and decrease the vigor due to a lower number of germinated seeds per day. There was a reduction in the mass of thousand seeds upon increasing the flooding period (Figure 1a). The mass of thousand seeds reached the maximum response point at $20 \mathrm{~h}$, leading to a reduction of $74 \%$ in yield for seeds produced in $72 \mathrm{~h}$ of flooding compared to those produced at field capacity. This physical attribute of seeds is related to the amount of assimilates allocated during their development, and seeds that develop in a more favorable environment, tend to reach a higher mass of thousand seeds (Peske et al., 2012).

It should be noted that seed weight depends on the size and duration of the functioning of the photosynthetic apparatus and photosynthate translocation efficiency of the seed filling period and soil and climatic conditions during the development of the mother plant and seeds (Vieira Junior and Dourado Neto, 2008). In this sense, soil flooding alters the hormonal balance of the plant so that, in water overflow situations, plants reduce the diffusion of ethylene out of the cells into the root system by increasing the endogenous concentration, resulting in senescence and leaf fall (Yin et al., 2009).

During flooding, carbon fixation by the photosynthetic process is adversely affected due to a lower oxygen diffusion and reduction of gas exchange between the root system and pore spaces where they develop (Magalhães and Souza, 2011), resulting in a decreased production of ATP and an inappropriate plant development (Horchani et al., 2008).

The number of seeds per ear fitted the quadratic model with a high coefficient of determination $\left(R^{2} \geq 0.99\right)$. It reduced by increasing the flooding period, reaching the maximum response point at $37 \%$ (Figure $1 \mathrm{~b}$ ). These results can be explained because flooding occurred between the V8 and V9 development stages, and the number of seeds per ear was defined between the V9 and V12 stages (Magalhães and Souza, 2011). In the 

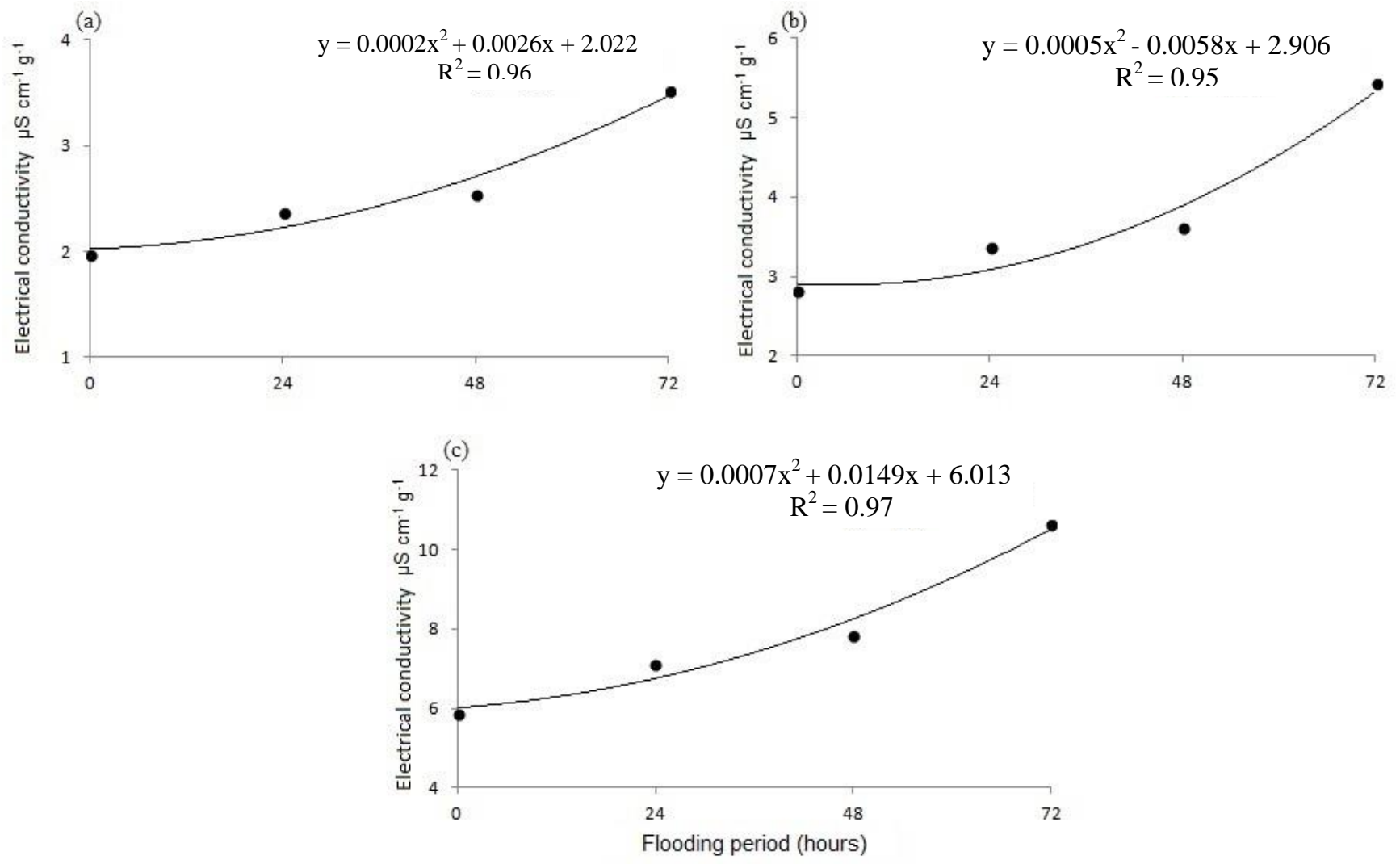

Figure 2. Electrical Conductivity after $3 ; 6$ and $24 \mathrm{~h}(\mathrm{a} ; \mathrm{b} ; \mathrm{c})$ corn seed imbibition ( $Z$. mays L.) produced by plants under different periods of flooding, and 0 (DC); $24 ; 48$ and $72 \mathrm{~h}$ temporary flooding.

V12 development stage, the occurrence of environmental stress adversely affects the number of ovules per row, and consequently the number of seeds. However, the level of damage caused to the ear depends on the duration and intensity of the stress. In a short and high intensity period, damage may occur at any place of the ear (Magalhães and Souza, 2011). The number of rows per ear fitted the quadratic model with a high coefficient of determination $\left(R^{2} \geq 0.96\right)$, reaching the maximum response point at $2.15 \%$ (Figure 1c). Regarding ears produced by plants kept at field capacity, there was a reduction of $0.95,1.45$ and $4.30 \%$ in the number of rows of plants subjected to flooding periods of 24,48 and $72 \mathrm{~h}$, respectively. According to Magalhães et al. (2002), the number of rows per ear is defined at the V8 stage, which corresponds to the plant vegetative stage with eight leaves. Therefore, any stress occurring at this development stage of corn plants may adversely affect the formation of the number of rows per ear.

The electrical conductivity (Figure 2) evaluated in seeds subjected to different flooding periods after 3,6 and $24 \mathrm{~h}$ of soaking fitted the quadratic model with a high coefficient of determination $\left(R^{2} \geq 0.99\right)$. There was an increase in the release of electrolytes with the increasing stress imposed and soaking time. After $3 \mathrm{~h}$ of soaking, there was a superiority of $0.41,0.58$ and $1.55 \%$ (Figure 2a) in the release of electrolytes from seeds produced by plants subjected to temporary flooding of 24,48 and $72 \mathrm{~h}$, respectively, compared to seeds produced at field capacity. After $6 \mathrm{~h}$ of soaking, the seeds produced with a temporary flooding of 24,48 and $72 \mathrm{~h}$ showed a superiority in exudate bleaching of $0.56,0.79$ and $2.61 \%$ (Figure 2b), respectively, compared to seeds at field capacity. At $24 \mathrm{~h}$ of soaking, seeds produced in 24,48 and $72 \mathrm{~h}$ were superior than those produced at field capacity at 1.27, 1.97 and $4.76 \%$ (Figure 2c), respectively. In this sense, at all evaluated times of soaking, seeds produced by plants subjected to flooding showed less ability to reorganize the cell membrane system. The efficiency in keeping the integrity of cell membranes is essential for the resumption of an efficient respiration process via oxidation, which provides energy, through the compounds, for the development of seedlings, maintaining a high relation with the maximum expression of seed vigor (Marcos Filho, 2005).

The lesser reorganization capacity of the cell membrane system may be related to the change in the pattern of development of the species, which, according to Hua Wu et al. (2009), shows a classic seed development pattern, presented by orthodox seeds, 

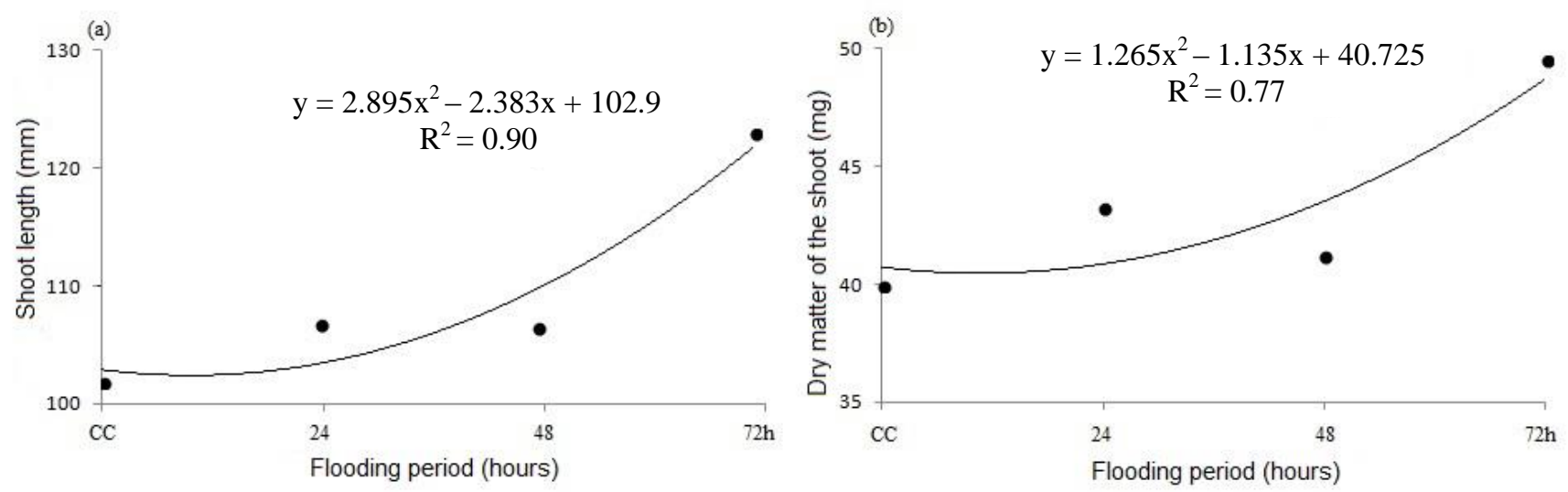

Figure 3. Length (a) and dry matter of the shoot (b) of maize seedlings ( $Z$. mays L.) subjected to flooding. Where: $0 ; 24 ; 48$ and $72 \mathrm{~h}$ temporary flooding.

comprising the synthesis and allocation of carbohydrates, lipids and proteins. In the final formation phase, there is the deposition of LEA proteins and raffinose oligosaccharides, which act to stabilize cell membranes providing tolerance to a dehydration process (Ferreira and Borghetti, 2008). Stress may change the preference of the metabolic drain for certain compounds, reducing its deposition and seed quality (Gehling et al., 2015). Shoot length and dry matter fitted the quadratic model $\left(\mathrm{R}^{2} \geq\right.$ 0.91 and 0.77 ). There was a significant increase in these two growth attributes in seedlings from seeds produced under the influence of $72 \mathrm{~h}$ of temporary flooding (Figure 3). For shoot length and dry matter, they were, compared to seeds produced by plants kept at field capacity, an increase of 21 and $10 \%$ in seedlings originated from seeds produced under $72 \mathrm{~h}$ of flooding. The increase in shoot length contributes to the increase in dry matter (Burgos et al., 2004). In seedlings from seeds produced under the influence of flooding, there was evidence of higher carbon allocation efficiency, even when produced seeds achieved a greater release of electrolytes according to electric conductivity tests (Figure 2). The allocation of dry matter relates with efficiency of hydrolysis and translocation of assimilates. It is thus, an indication of seed quality (Carvalho et al., 2011). For the species $B$. brizantha, which is from the same family as corn, some cultivars produce a greater shoot dry mass when subjected to flooding (Kroth et al., 2015). Flooding negatively affects corn plants concerning yield, mass of thousand seeds, number of seeds per ear, number of rows per ear and seed vigor. However, when evaluating the quality of seeds and the physiological performance of seedlings, there was an increase in shoot length and dry matter.

\section{Conclusion}

Temporary flooding in the studied development stages led to the results obtained. Temporary flooding affects physiological performance and yield attributes of corn seeds according to stress period; With the increase in the flooding period in up to $72 \mathrm{~h}$, there is an increase in electrolyte leaching in corn seeds; Seeds produced in 72 $\mathrm{h}$ of flooding showed a reduced mass of thousand seeds, number of seeds per ear and number of rows per ear.

\section{Conflict of Interests}

The authors have not declared any conflict of interests.

\section{REFERENCES}

Araya T, Noguchi K, Terashima I (2006). Effects of carbohydrate accumulation on photosynthesis differ between sink and source leaves of Phaseolus vulgaris L. Plant Cell Physiol. 47(5):644-652.

Bailey-Serres J, Voesenek LACJ (2008). Flooding Stress: Acclimations and Genetic Diversity. Ann. Rev. Plant Biol. 59:313-339.

Borghi E, Crusciol CAC (2007). Produtividade de milho, espaçamento e modalidade de consorciação com Brachiria brizantha em sistema plantio direto. Pesqui. Agropecu. Bras. 42(2):163-171.

Brachtvogel EL, Pereira FRS, Cruz SCS, Bicudo SJ (2009). Densidades populacionais de milho em arranjos espaciais convencional e equidistante entre plantas. Ciênc. Rural. 39(8):2334-2339.

Brasil. Ministério da Agricultura, Pecuária e Abastecimento (2009). Regras para análise de sementes. Brasília: Secretaria de Defesa Agropecuária. P 395.

Burgos NR, Talbert RE, Kim KS, Kuk YI (2004). Growth inibition and root ultrastructure of cucumber seedlings exposed to allelochemicals from rye. J. Chem. Ecol. 30(3):671-690.

Caetano LPD, Dais-Filho MB (2008). Resposta de seis acessos de capim-braquiária ao alagamento do solo. Rev. Bras. Zootec. 37(5)795-801.

Carvalho FD, Santos JB, Cury JP, Valadão Silva D, Braga RR, Byrro ECM (2011). Alocação de matéria seca e capacidade competitiva de cultivares de milho com plantas daninhas. Plantas Daninha. 29(2):373-382.

Conab (2015). Companhia Nacional de Abastecimento. Acompanhamento de safra brasileira 2014/15: grãos, décimo segundo levantamento. Brasília: Conab, 2015.

Cqfs (2004). Manual de adubação e de calagem para os Estados do 
Rio Grande do Sul e de Santa Catarina. Sociedade Brasileira de Ciência do Solo. Comissão de Química e Fertilidade do Solo. 10. ed. Porto Alegre. P 400.

Dias-Filho MB (2005). Opções forrageiras para áreas sujeitas à inundação ou alagamento temporário. In: Pedreira CGS, Moura JC, Da Silva SC, Faria VP. Teoria e prática da produção animal em pastagens. In: Simpósio sobre manejo da pastagem, 22, 2005, Piracicaba. Anais...Piracicaba: FEALQ. pp. 71-93.

EMBRAPA - Centro Nacional de Pesquisa de Solos (1999). Sistema Brasileiro de Classificação de Solos. P 412.

Ferreira AG, Borghetti F (2008). Germinação: do básico ao aplicado. Porto Alegre: Artmed. P 275.

Gazolla NA, Aumonde ZT, Pedó T, Olsen D, Villela AF (2012). Níveis de umidade do solo de várzea e seus efeitos sobre a emergência e crescimento inicial de plântulas de soja. ABRATES 22(2):28-31.

Gehling VM, Pedó T, Martinazzo EG, Aumonde TZ, Villela FA (2015). Effect of soil waterlogging stress on the physiological performance of seeds and on the productivity of rye plants. Agrocienc. 19(1):41-47.

Horchani F, Gallusci P, Baldet P (2008). Prolonged root hypoxia induces ammonium accumulation and decreases the nutritional quality of tomato fruits Journal of plant physiology. J. Plant Physiol. 165(13):1352-1359.

Hua Wu J, Wang WQ, Song SQ, Cheng HY (2009). Reactive oxygen species scavenging enzymes and down-adjustment of metabolism level in mitochondria associated with desiccation-tolerance acquisition of maize embryo. J. Integr. Plant Biol. 51(7):638-645.

Irfan M, Hayat S, Hayat Q, Afroz S, Ahmad A (2010). Physiological and biochemical changes in plants under waterlogging. Protoplasma 241:3-17.

Kroth BE, Silva BEM, Silva TJA, Koetz M, Schlichting AF (2015). Cultivares de Brachiaria brizantha sob diferentes disponibilidades hídricas em Neossolo Flúvico. Rev. Bras. de engenharia agrícola e ambiental. 19(5):464-469.

Ludwig MP, Schuch LOB, Vernetti Junior FdeJ, Seus R, Crizel RL (2010). Germinação e vigor de sementes de soja produzida em solo de várzea alagada. Pelotas: Embrapa Clima Temperado. pp. 59-68.
Magalhães PC, Durães FOM, Carneiro NP, Paiva E (2002). Fisiologia do milho. Sete Lagoas: (Embrapa-Cnpms. Circular Técnica, 22). $\mathrm{P}$ 22.

Magalhães PC, Souza TC (2011). Cultivo do Milho: Ecofisiologia. Embrapa Milho e Sorgo. Versão eletrônica - 8ª edição.

Marcos Filho J (2005). Fisiologia de sementes de plantas cultivadas. Piracicaba: Fealq. P 495.

Nakagawa J (1994). Testes e vigor baseados na avaliação de plântulas. In: Vieira RD, Carvalho NM. (Ed.). Testes de vigor em sementes. Jaboticabal: FUNEP. pp. 49-85.

Peske ST, Villela FA, Meneguello GE (2012). Sementes: Fundamentos Científicos e Tecnológicos, 3 ed. P 573.

Pryor RJ, Davison NJ, Close DC (2006). Waterlogging duration; Interspecific comparison of Leptospermum scoparium (Forst et Forst.f.), Acacia melanoxylon (R. Br.), Nothofagus cunninghamii (Hook.) and Eucalyptus obliqua (L'Herit). Aust. Ecol. 31:408-416.

Schmidt F, Fortes MA, Botolon L, Botolon ESO, Sousa RO (2010). Nível crítico de toxidez do ácido acético em culturas alternativas para solos de várzea. Ciênc. Rural. 40(5):1068-1074.

Thomas AL, Costa JA (2010). Soja: manejo para alta produtividade de grãos. Porto Alegre: Evangraf. P 243.

Vieira JPA, Dourado ND (2008). In: Castro PRC, Kluge RA, Sestari I (Eds.) Manual de fisiologia vegetal: fisiologia de cultivos. $1^{\underline{a}}$ ed. Piracicaba, Ceres. pp. 130-156.

Yin D, Chen S, Chen F, Guan Z, Fang W (2009). Morphological and physiological responses of two chrysanthemum cultivars differing in their tolerance to waterlogging. Environ. Exp. Bot. 67:87-93. 